\title{
A Study on the Clinical Characteristics of Pulmonary TB Patients
}

\author{
Dr. Md. Zahidur Rahman ${ }^{1 *}$, Dr. C. M. Reza Qureshi Forhad ${ }^{2}$, Dr. Md. Enayet Karim ${ }^{3}$
}

${ }^{1}$ Secretary the State Medical Faculty of Bangladesh, Dhaka, Bangladesh

${ }^{2}$ Professor (cc), Department of Biochemistry, US-Bangla Medical College, Rupganj, Narayanganj, Bangladesh

${ }^{3}$ Associate Professor (cc), Depart of Community Medicine, US-Bangla Medical College, Rupganj, Narayanganj, Bangladesh

DOI: $10.36347 /$ sjams.2021.v09i01.002

| Received: 15.12.2020 | Accepted: 26.12.2020 | Published: 04.01.2021

*Corresponding author: Dr. Md. Zahidur Rahman

Abstract

Original Research Article

Objective: In this study our main goal is to evaluate the clinical status of pulmonary TB patients. Method: This prospective and observational study was carried out during the period of 1st January 2010 to 31st December 2010, in the Department of Biochemistry, Sylhet M.A.G Osmani Medical College, and DOT centre, Sylhet M.A.G Osmani Medical College Hospital, Sylhet. A total of 76 subjects, both male \& female 15 and 60 years of age were included in the study. Out of them 46 were smear positive newly diagnosed pulmonary tuberculosis patient (cases) and 30 were age-matched healthy subjects (control). Results: During the study, all patients were presented with weight loss followed by $95.7 \%$ had cough, fever had $84.8 \%$ cases, $34.8 \%$ had haemoptysis, $50 \%$ had chest pain. Mean ( \pm SD) serum CRP level $(\mathrm{mg} / \mathrm{l})$ were $79.59( \pm 22.71)$ and $7.5( \pm 1.68)$ in cases and controls respectively at the time of diagnosis. An unpaired t-test was conducted to compare serum level of C-reactive protein between cases and controls. Serum CRP level was significantly higher in cases than controls ( $\mathrm{p}<0.001) .71 .7 \%$ cases had unilateral opacities, 28.3\% had bilateral opacities. $13 \%$ had cavity on chest radiograph. Conclusion: From our study we can conclude that, early diagnosis will prevent mortality and morbidity from this dreadful but curable disease. The available epidemiology in Bangladesh is presented in this study, but requires further study in a large scale.

Keywords: Pulmonary Tuberculosis, mycobacterium tuberculosis, clinical status.

Copyright $(\mathcal{2 0 2 1}$ The Author(s): This is an open-access article distributed under the terms of the Creative Commons Attribution 4.0 International License (CC BY-NC 4.0) which permits unrestricted use, distribution, and reproduction in any medium for non-commercial use provided the original author and source are credited.

\section{INTRODUCTION}

Tuberculosis (TB) can affect almost any organ of the body and although the most common presentation is pulmonary, extra pulmonary disease is not rare [1]. The sites involved in extra-pulmonary tuberculosis are lymph nodes, abdomen, bones, and joints including spine, genitourinary system and central nervous system. Some patients may present with miliary tuberculosis. Others may present with abscess, fistula and cutaneous lesion [2]. Presentation of extrapulmonary disease may be a typical or relatively insidious and tuberculosis may not be considered initially in differential diagnosis. This is an important phenomenon as delay in diagnosis may be crippling or even life threatening [3].

In Bangladesh, TB control program is implemented in partnership with NGOs. Several private and corporate sectors are involved in TB control and in rendering services in line with international standards for TB care[4]. In this study our main goal is to evaluate the clinical status of pulmonary TB patients.

\section{OBJECTIVE}

- To assess the clinical status of pulmonary TB patients.

\section{MeTHOdOLOGY}

Study type: This was a prospective and observational study.

Study place and period: This study was conducted during the period of 1st January 2010 to 31st December 2010, in the Department of Biochemistry, Sylhet M.A.G Osmani Medical College, and DOT centre, Sylhet M.A.G Osmani Medical College Hospital, Sylhet.

Study population: A total of 76 subjects, both male \& female 15 and 60 years of age were included in the study. Out of them 46 were smear positive newly diagnosed pulmonary tuberculosis patient (cases) and 30 were age-matched healthy subjects (control). Cases were selected purposively from DOT center of Sylhet MAG Osmani Medical College Hospital after diagnosed as new smear positive pulmonary 
Zahidur Rahman et al; Sch J App Med Sci, Jan, 2021; 9(1): 11-13

tuberculosis patients \& controls were selected from healthy volunteers.

Sputum smear negative pulmonary tuberculosis patient or patients having history of taking anti-TB drugs or patients of pulmonary TB with associated connective tissue disorders are excluded from the study.

Method: Detailed history, clinical examination and laboratory data were recorded. Then blood sample was collected from all the subjects after informed written consent. Blood samples were tested for Creactive protein. After two months of starting antitubercular therapy when patient came for follow up again laboratory data were recorded and blood sample was collected for ESR and C-reactive protein. CRP was also evaluated only once, in the group of healthy control. Serum C-reactive protein (CRP) concentration was measured by immunonephelometric method \& Erythrocyte sedimentation rate (ESR) was determined in Westergren's method.

As a comparative index of response to treatment sputum microscopy for AFB were tested on two occasions- before starting and after two months of treatment. Reporting of sputum smear:

1-9 AFB per 100 oil immersion fields : To mention the exact number (Scanty)

10 -100 AFB per 100 oil immersion fields : $1+$

1-10 AFB per oil immersion fields : $2+$

>10 AFB per oil immersion fields : : $3+$

\section{DAta AnAlysis}

All data were analyzed with the help of SPSS for windows version 15, using the relevant tests of significance such as Student's 't'-test, Pearson correlation analysis was done to elucidate association between variables. $\mathrm{P}$ value $<0.05$ was taken as level of significance.

\section{RESULTS}

In table-1 shows age distribution of the patients. Mean age of the cases was 33.41 years with a range of 16-55 years. Mean age of the controls was 34.57 years with a range of $18-55$ years. The following table is given below in detail:

Table-1: Distribution of the age of the study subjects

\begin{tabular}{|l|l|l|l|l|}
\hline Groups & Age in years & Age range (Years) & t-value & p-value \\
\cline { 1 - 3 } Case $(\mathrm{n}=46)$ & $33.41 \pm 11.1$ & $16-55$ & & \\
\cline { 1 - 2 }$(\mathrm{n}=30)$ & $34.57 \pm 10.92$ & $18-55$ & 0.447 & $<0.657$ \\
\hline
\end{tabular}

In figure-1 shows gender distribution of the patients where most of the patients were male, $63 \%$. The following figure is given below in detail:

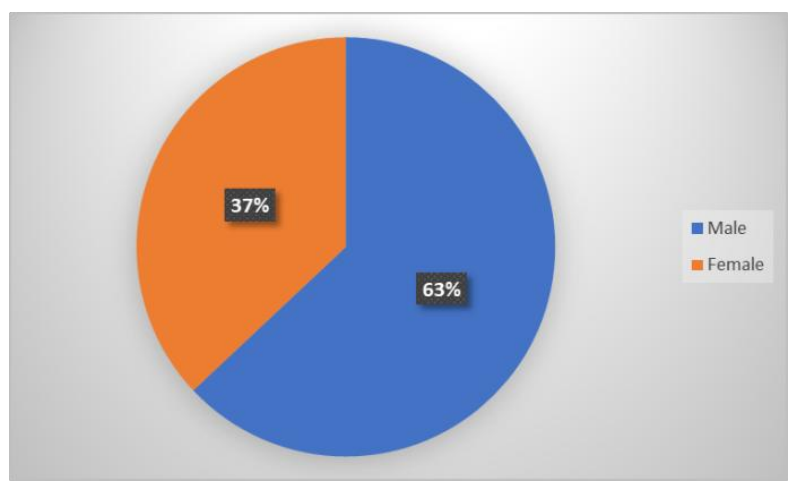

Fig-1: Gender distribution of the patients

In table-2 shows clinical presentation of the patients where all patients were presented with weight loss followed by $95.7 \%$ had cough, fever had $84.8 \%$ cases, $34.8 \%$ had haemoptysis, $50 \%$ had chest pain. The following table is given below in detail:

Table-2: Clinical presentation of the patients
\begin{tabular}{|l|l|}
\hline Clinical presentation & $\%$ \\
\hline Weight loss & $100 \%$ \\
\hline Cough & $95.7 \%$ \\
\hline Fever & $84.8 \%$ \\
\hline Haemoptysis & $34.8 \%$ \\
\hline Chest Pain & $50 \%$ \\
\hline
\end{tabular}

In table-3 shows CRP level of the patients where mean $( \pm \mathrm{SD})$ serum CRP level $(\mathrm{mg} / \mathrm{l})$ were 79.59 $( \pm 22.71)$ and $7.5( \pm 1.68)$ in cases and controls respectively at the time of diagnosis. An unpaired t-test was conducted to compare serum level of C-reactive protein between cases and controls. Serum CRP level was significantly higher in cases than controls ( $p$ $<0.001)$. The following table is given below in detail:

Table-3: CRP in cases and controls

\begin{tabular}{|l|c|l|l|}
\hline Groups & CRP $(\mathrm{mg} / \mathrm{l})$ & t-value & p-value \\
\cline { 1 - 2 } Case $(\mathrm{n}=46)$ & $79.6 \pm 22.7$ & & \\
\cline { 1 - 2 } Control $(\mathrm{n}=30)$ & $7.5 \pm 1.7$ & 21.44 & $<0.001$ \\
\hline
\end{tabular}

Unpaired Student's-t test was done and $\mathrm{p}<0.05$ taken as significant. In table-4 shows comparison of CRP in cases based on CXR findings where $71.7 \%$ cases had unilateral opacities, $28.3 \%$ had bilateral opacities. $13 \%$ had cavity on chest radiograph. The following table is given below in detail: 
Table-4: Comparison of CRP in cases based on CXR findings

\begin{tabular}{|l|l|l|l|l|}
\hline CXR findings & $\%$ & CRP level (mg/I) & t-value & p-value \\
\hline $\begin{array}{l}\text { Opacities: } \\
\text { Unilateral }\end{array}$ & $71.7 \%$ & $72.54 \pm 20.46$ & 3.8 & $<0.001$ \\
Bilateral & $28.3 \%$ & $97.46 \pm 18.28$ & & \\
\hline Cavity: & & & & \\
Present & $13.04 \%$ & $123 \pm 15.92$ & 7.49 & \\
Absent & $86.96 \%$ & $73.07 \pm 15.13$ & & \\
\hline
\end{tabular}

\section{DISCUSSION}

Pulmonary tuberculosis (PTB) remains one of the deadliest diseases worldwide. Despite extensive tuberculosis control efforts in the past by WHO and local health departments, the tuberculosis epidemic continues to ravage the developing world; affecting all susceptible individuals [5]. The WHO aims to reduce the global incidence of active TB to less than 1/100,000 per year by 20508. Poor treatment outcome has serious consequences, including ongoing infectivity and development of drug-resistant Mycobacterium tuberculosis9. A study highlighted the fact that CRP can be a marker of TB treatment response and early evaluation of the response to treatment may improve routine clinical management [6].

In one study reported that, the patients presented with abdominal pain and distension were $22.5 \%$ and $17.5 \%$ respectively. These were the patients of abdominal tuberculosis, which is $35 \%$ in this study [7]. It is similar to data of Medical Research Council. Surveyed in 1983 for Indian subcontinent (ISC) ethnic group in which lymph node tuberculosis was $52 \%$ followed by abdominal tuberculosis (14\%) [8]. Where as in our study all patients were presented with weight loss followed by $95.7 \%$ had cough, fever had $84.8 \%$ cases, $34.8 \%$ had haemoptysis, $50 \%$ had chest pain.

During the study, mean $( \pm$ SD) serum CRP level $(\mathrm{mg} / \mathrm{l})$ were $79.59( \pm 22.71)$ and $7.5( \pm 1.68)$ in cases and controls respectively at the time of diagnosis. An unpaired t-test was conducted to compare serum level of C-reactive protein between cases and controls. Serum CRP level was significantly higher in cases than controls $(\mathrm{p}<0.001)$. Which was supported by several studies $[9,10]$.

\section{Conclusion}

From our study we can conclude that, early diagnosis will prevent mortalityand morbidity from this dreadful but curable disease. The available epidemiology in Bangladesh is presented in this study, but requires further study in alarge scale.

\section{REFERENCES}

1. Reid PT, Innes JA. Respiratory diseases (Tuberculosis), In: Colledge NR, Walker BR, Ralston SH (eds). Davidson's principles and practice of medicine. (21stedn), Churchill Livingstone, Elsevier, Edinburgh. 2010: 688

2. Global Tuberculosis Control. World Health Organization report. 2010:1-65

3. Lopez AD. Global burden of disease and risk factors. New York, Oxford University Press and the World Bank. 2006: 1-54

4. Pitchenik AE, Fertel D, Bloch AB. Pulmonary effectsof AIDS: Mycobacterial diseaseepidemiology, diagnosis, treatment, and prevention. Clin. Chest Med. 1988; 9: 425-41.

5. Wolinsky E. Tuberculosis, Wyngaarden JB, Smith LHeditors. In Cecil Textbook of Medicine, 18th edn. W. B. Saunders, Philadelphia. 1988; 2: 1682 92.

6. Faiz MA. Extrapulmonary tuberculosis in Bangladesh -Areview of 47 cases. J Bangladesh Coll Phys and Surgeon. 1990; 7: 1-7.

7. Alvarez S and McCabe WR. Extrapulmonary tuberculosisrevisited: A review of experience at Boston city and otherhospitals. Medicine. 1984; 1: 25-55.

8. Farer LS, Lowel AM and Meador MP. Extrapulmonarytuberculosis in the United States. AM J Epidemiol.1979; 109: 205-217?

9. Moktar A and Salman K. Extrapulmonary tuberculosis. Saudi Med. J. 1983; 4: 317.

10. Froude JR and Land Kingston M. Extrapulmonarytuberculosis in Saudi Arabia. A review of 162 cases. KingFaisal Specialist Hosp. Med. J. 1982; 2: 85. 